\section{Normal Susceptibility Levels of Anopheles pharoensis Theobald to DDT and Dieldrin}

House spraying with residual insectieides, particularly with DDT and dieldrin, plays an important part in modern anti-malaria campaigns. The tolerance of malaria vectors to these toxicants is therefore of special interest. Assessments of the susceptibility of many different species of anopheline mosquitoes before and during spraying operations have been carried out in many parts of the world ${ }^{1}$. However, nothing seems to have been published on the normal resistance-level of $A$. pharoensis, a vector of malaria in several countries of Africa.

A number of tests have been carried out on this species in the village of Natsini, $10 \mathrm{~km}$. outside the sprayed area of the Mass Malaria Control Campaign in Sokoto Province, Northern Nigeria. Wild females were obtained at night from a donkey-baited hut soon after they had engorged. In the following morning they were exposed for $1 \mathrm{hr}$. to filter papers impregnated with insecticide using the World Health Organization adult test method, a modification of the Busvine test ${ }^{2,3}$. The exposure-time was followed by a recovery-period of $24 \mathrm{hr}$., during which the mosquitoes were kept in unwaxed paper cups provided with cotton wool soaked in sugar solution. Then the results were read.

The temperature and humidity during the time of testing varied from $24^{\circ} \mathrm{C}$. to $28 \cdot 4^{\circ} \mathrm{C}$, and 74 to 85 per cent respectively, and the range of temperature during the recovery-period was $20-30^{\circ} \mathrm{C}$. The results obtained are shown in Table 1.

Table 1

\begin{tabular}{|c|c|c|c|c|}
\hline \multirow{2}{*}{$\begin{array}{c}\text { Insecticide } \\
\text { DDT }\end{array}$} & \multirow{2}{*}{$\begin{array}{c}\begin{array}{c}\text { Concentration } \\
\text { (per cent) }\end{array} \\
0 \cdot 25 \\
0 \cdot 5 \\
1 \cdot 0 \\
2 \cdot 0 \\
4 \cdot 0 \\
4 \cdot 0^{*} \\
\end{array}$} & \multicolumn{2}{|c|}{$\begin{array}{l}\text { No. of mosquitoes } \\
\text { exposed }\end{array}$} & \multirow{2}{*}{$\begin{array}{c}\text { Mortality } \\
\text { (yer cent) } \\
2 \\
12 \\
33 \\
71 \\
97 \\
100 \\
0\end{array}$} \\
\hline & & $\begin{array}{r}80 \\
240 \\
226 \\
307 \\
245 \\
98 \\
163\end{array}$ & $\begin{array}{r}2 \\
30 \\
75 \\
218 \\
239 \\
98 \\
0\end{array}$ & \\
\hline Dieldrin & $\begin{array}{l}0.05 \\
0 \cdot 1 \\
0.2 \\
0 \cdot 4 \\
-\end{array}$ & $\begin{array}{l}243 \\
288 \\
233 \\
227 \\
134\end{array}$ & $\begin{array}{r}20 \\
100 \\
186 \\
223 \\
1\end{array}$ & $\begin{array}{r}8 \\
35 \\
80 \\
98 \\
1\end{array}$ \\
\hline
\end{tabular}

* Exposure time, 2 hr.

The median lethal concentrations ( $L C 50$ ) have been estimated graphically on the dosage-mortality lines drawn on logarithmic-probability paper. They were for DDT 1.5 and for dieldrin 0.14 per cent.

Susceptibility-levels, estimated for many different species of anopheline mosquitoes from untreated areas, have shown surprisingly little variation of the $L C 50^{4}$. It varies between 0.5 and 1.5 for DDT and between 0.05 and 0.15 per cent for dieldrin. The figures obtained in the present communication lie in the range of these variations and indicate a normal susceptibility of $A$. pharoensis to these insecticides.

Mass Malaria Control Campaign, F. KuHLOW

Birnin Kebbi,

Solkoto Province,

Northern Nigeria.

${ }^{1}$ World Health Organization, Bull. WHO, 16, 874 (1957).

${ }^{2}$ Busvine, J. R., and Nash, R., Bull. Entom. Res., 44, 371 (1953).

${ }^{3}$ World Health Org., Tech. Report Series, 80, 30 (1954).

4 World Health Organization, WHO/Mal/203 (1958).

\section{Mortality and Viability of Insect Migrants High in the Air}

Entomologists have long been aware that vast numbers of insects are distributed up to thousands of feet in the air on any warm day ${ }^{1}$. The men who collected evidence of this assumed that the insects were alive ${ }^{2-4}$. However, the trapping methods they used killed most of the insects so that mortality and viability could not be assessed. Other entomologists have been less confident of the vitality of insects dispersing regularly by such flights, perhaps because of a belief that an ascent to, say, 5,000 ft. means a flight of many hours; this is not necessarily $\mathbf{s o}^{5}$. Nevertheless, it is not generally accepted that this mode of transport is no more lethal than flight near the ground ${ }^{6}$.

Insects have therefore been collected between 1,000 and 5,000 ft. at Cardington, Bedfordshire, England, with the kind co-operation of Mr. L. A. Speed and the staff of the Research and Development Establishment, to see what percentage of insects at these levels are alive and undamaged. The insects were caught in a vertical series of 6 nets, suspended from a balloon cable and opened for some hours between 09.00 and $16.00 \mathrm{hr}$. G.M.T. in June, July, August and September 1959. A mechanism opened the nets after ascent and closed them before descent?

Out of 1,610 insects caught, 1,57 I (97 per cent) were alive and undamaged; 25 ( 2 per cent) were alive but damaged ; 14 (1 per cent) were dead, when the nets were opened. Most of the damage to insects and some of the mortality were certainly caused by handling the nets. Mortality was probably also increased by the long time (up to $5 \mathrm{hr}$.) that some insects spent in the net after capture, exposed to the desiccating action of the wind. It may be assumed that the insects had, on average, completed half their aerial flight when they were caught, for the air almost clears of insects at night ${ }^{1}$. It can therefore be said with confidence that, of insects flying up to 1 mile high over southern England in mild summer weather, less than 2 per cent die in transit, except by predation or other means that leave no trace.

It is not possible to assess the viability of these insects quantitatively because it is often difficult or impossible to identify them at once and the pattern of reproductive behaviour is rarely known. However, some insects did reproduce, and living offspring were obtained from the following agricultural pests : cabbage aphid, Brevicoryne brassicae L. ; peach-potato aphid, Myzus persicae Sulz. ; bean aphid, A phis fabae Scop. ; frit fly, Oscinella frit L. ; hessian fly group, Mayetiola sp., possibly destructor Say.

Many other insects, not yet identified, also reproduced successfully. Although not the smallest of insects, these include some of the most fragile. This seems to establish the viability of high-level migrants beyond reasonable doubt.

\section{R. TAYLOR}

Department of Entomology,

Rothamsted Experimental Station, Harpenden.

${ }^{1}$ Johnson, C. G., Sci. Prog. Twent. Cent., 39, 41 (1951).

${ }^{2}$ Glick, P. A., Tech. Bull. U.S. Dep. Agric. No. 673 (1939).

${ }^{3} \mathrm{Hardy}$, A. C., and Milne, P. S., J. Anim. Ecol., 7, 199 (1938).

4 Johnson, C. G., J. Anim. Ecol., 26, 479 (1957).

5 Taylor, L. R., Proc. Linn. Soc., 169, 67 (1958).

- Andrewartha, H. G., and Birch, L. C., "The Distribution and Abundance of Animals", 109 (Chicago, 1954).

T.Johnson, C. G., and Taylor, L. R., Lab. Pract., 4, 235 (1955). 